\title{
Real Estate Bubbles in China, Causes and Future Expectations/Solutions
}

\author{
J. Salim, Y. Ren, and X. Fang
}

\begin{abstract}
China is still experiencing rapid economic growth (with GDP annual growth rate $6.7 \%$ in $\mathrm{Q3} \mathrm{2016).} \mathrm{While} \mathrm{China}$ is becoming more urbanized and modernized after the reform period, one can witness from the other side, the asset market boom (especially real estate boom) which triggers anxiety to economists and financial experts.

What is the real estate bubble or boom? What are the causes of real estate exuberance? Is there a trend in the real estate prices? If the bubble burst then what are the glimpse consequences on china's economy? How can we prevent the asset bubbles from growing or in other words, what are the precautions and proactive ways central bank of China should take concerning the monetary policy to condone the bubble's growth? This paper will shed-light on the causes of this real estate bubble and how to solve it using autoregressive (AR) and autoregressive distributed lag (ADL) models.
\end{abstract}

Index Terms-Autoregressive model (AR), autoregressive distributed lag (ADL) model, lending rates, real estate bubble.

\section{INTRODUCTION}

Real Estate bubble is the state of capitalism after a post-industrial macroeconomic growth that is based largely on appreciation of real estate.

"It occurs when speculation in the underlying asset causes price to increase, thus encouraging more speculation. The prices can rise to absurd or unsustainable levels (that no longer reflect utility of usage and purchasing power) and it becomes impossible to predict from supply and demand alone. The bubble is usually followed by a sudden drop in prices, known as a crash or a bubble burst." [1].

There are drivers for this real estate boom such as the excess of liquidity resulting from strong exports. China has to take strict rules and precautions in the monetary policy in order to have liquidity relief with high level of foreign exchange reserves and low loan deposit ratios.

Thus, the real estate-bubble economy is triggered usually by low interest rate to simulate the borrowing which helps financing the purchase of houses at a rate sufficient to sustain the upward trend in prices.

The growth of Chinese GDP over a period of more than three decades was one of the factors for the tremendous increase in the demand for housing and in the development of building industry. Also, credits were given easily (low interest rates), especially the shadow banking loans during the

Manuscript received March 3, 2017; revised July 7, 2017.

The authors are with the School of Economics, Shandong University, China (e-mail: jana_salim11@live.com, ryy1996@163.com, fx_artemis@163.com). financial crisis 2008-2009.

China's market opening to trade, investments (FDI) and private enterprises construction (after reform 1978) are also main causes to the real estate bubble. So, these reforms lead to expanding global markets and huge foreign direct investments (almost more than 650 million \$) which arouse the real estate bubble. As a consequence, middle class increases in China and they wanted to move toward urban areas hence the request for mortgage increases too and this migration (rural-to-urban areas) generates public investments in real estate.

Within the context of the financial crisis 2008-2009, the US Government poured large excessive amounts of money into their economies to simulate the economic activity. So higher liquidity leads to more investments in real estate exacerbating the bubble problem. And this is actually happening in China after globalization.

Other Cause is RMB appreciation speculation, the surplus in trade forces China to buy more foreign currencies, especially US governments bonds and treasury bills. Therefore, this will lead to increase in depreciation of foreign currencies while on the other side it will give rise to an anticipation of RMB appreciation and speculation for profit on RMB appreciation.

The main contribution of our paper is to forecast not only the level of the real estate prices series in the China market and detecting their long-run trend but also using the autoregressive distributed lag model (ADL) to comprehend that real estate prices movements can be forecasted by the lending interest rate as the main target monetary policy the central bank should adopt.

\section{LITERATURE REVIEW}

The real estate prices have transformed to become a keen interest especially after the previous 2008 -finnacial crisis, and this has put forward a vast of research papers on this subject.

Mankiw and Weil (1989) [2] studied the prediction of prices up to twenty years in the future based on present and predictable changes in population. However, their studies remain controversial (e.g. [3], [4])

Case and Shiller [5], Clapp and Giaccotto (1994) [6] suggest that some variables (including for example population, expected inflation, unemployment and income) have considerable forecasting effect on housing price.

James A. Kahn (2009) [7], suggests also that home price movements can be linked to productivity changes. Changing economic main variables, such as, labor productivity has played an important role in shifting housing prices through their effects on income growth and long term income 
expectations.

The other part of the literature deals with methods for forecasting real estate prices. Some of this literature uses purely time series data to forecast for example house prices.

J. Baffoe (1998) [8] finds that the four key macroeconomic variables (the employment growth and mortgage rate at both the national and regional levels for the U.S) have dynamic sensitive effect on the housing prices using a VAR.

Clapp and Giaccotto (2002) [9] use an autoregressive model to forecast the city-wide house price index of Dade County, Florida.

Crawford and Fratantoni (2003) [10] use ARIMA, $\mathrm{GARCH}$, and regime switching univariate models to model the real estate market forecast in various parts of the US. They used state-level repeat transactions data for California, Florida, Massachusetts, Ohio, and Texas. Annualized growth rates at a quarterly frequency are computed from each of these indices from 1979:1 to 2001:4. The study found that ARIMA models are generally more suitable for out-of-sample forecasting and point forecasts.

According to Iacoviello (2005) [11], Iacoviello and Neri ( [12] ) and Vargas-Silva [13], the real estate sector and more specifically housing prices are one of the leading indicators for the economic activity in the U.S. For this reason, many researchers investigate the effects of monetary policy on housing prices.

Gupta et al. (2009) [14] indicate that housing prices in South Africa is negatively affected by monetary shocks.

Gupta and Das (2010) [15] used a Bayesian approach in predicting downturns in the US housing market in the period 2007:Q1-2008:Q1. Their result shows that the BVAR model, in any form, spatial and non-spatial (univariate and multivariate), is the best-performing model as well as doing a fair job in predicting the downturn against unrestricted the classical VAR model.

Residential property prices in Latvia are best explained by an autoregressive (AR) process [16]. This was concluded through the comparative evaluation of different univariate forecasting techniques (regressions, unobserved component model and ARIMA).

Skarbøvik (2013) [17] tried to model residential house prices in Norway by means of AR (14) model and an ARIMA $(2,1,1)$ model. The out-of-sample forecast depicted that the AR process surprisingly outperformed the ARIMA model.

Do and Holten (2013) [18] also relied on time series analysis to examine the house price index in Denmark and found out that it can be modeled by means of an AR process of order 3. In other words, Danish house price index is best explained by its previous three lags.

Kam C. Chan and Chih-Hsiang Chang (2014) [19] investigated the policy of using the lending rate to dampen China's real estate sector, by using a broad analysis of the stock, bond, and real estate markets in China.

Following the work of Gupta et al. (2009), in this paper we try to forecast housing prices in China taking into account the lending interest rate changes as the best monetary shock policy that should be taken by the Central Bank of China to mitigate the real estate bubble.

The core idea of the paper is that future appreciations or depreciations of interest rates in turn are important determinants of housing sale prices [20].

The rest of the paper is organized as follows, Section III analyses the data used, Section IV refers to the methodology, Section V discusses the empirical results, Section VI concludes.

\section{DATA}

The monthly average house-pricing in the main 100 cities of China (a section from the whole real estate categories) is investigated in this study. Both variables are collected from "Wind" data base. The study period is from June 2010 November 2016.

The monthly lending interest rate of China is used, but due to lack of available housing prices data, we have just adopted the data of lending interest rates for the period 2010-2016 too.

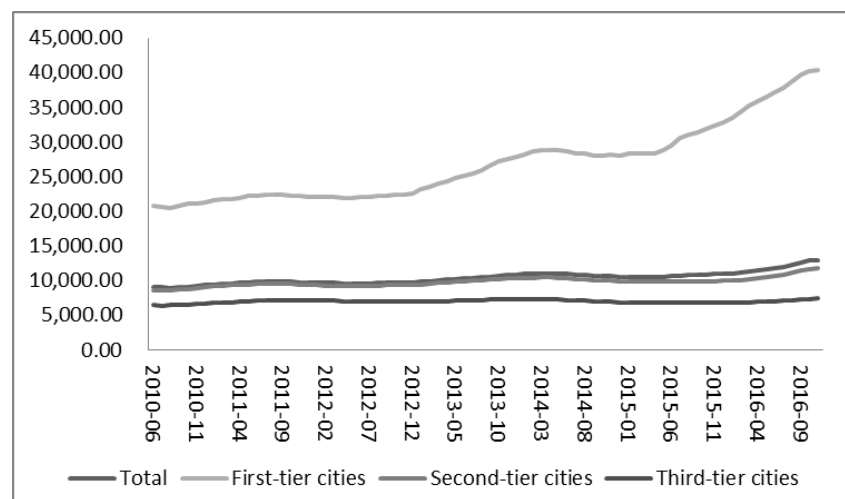

Fig. 1. Average housing prices (RMB) in 100 cities.

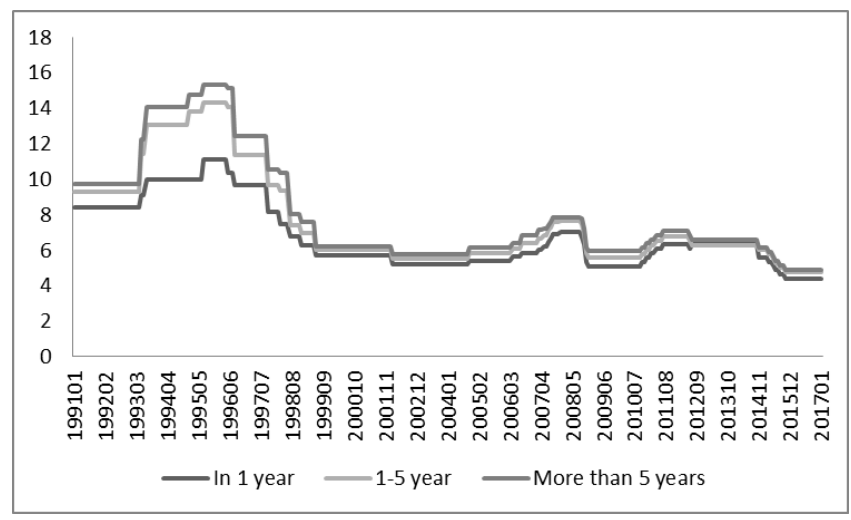

Fig. 2. Percentage changes of lending interest rates in China.

It has become clear that the expansion of real estate bubble (more than 100 percent rise) is booming especially in the first-tier cities (like in Beijing, shanghai, Guangzhou, Shenzhen etc.). Chinese people are more willing to purchase in these areas because it is closely linked to their high income level.

If we compare the two graphs, we can easily recognize the negative relationship in China between the two variables, (see Fig. 1, Fig. 2).

\section{MEthodology}

So, the Chinese government should intend to implement as we said before, economic policies to mitigate the threat of real estate bubble to emerge more. One of these policies is to 
tighten the interest rate. Raising lending rates or borrowing costs can be an effective way in inhibiting the rapid increase in real estate prices.

If lending rate increases then borrowing costs for real estate investors will increase but in the long run period (lags of one year and two years for example), thus the demand for mortgages decreases, and hence real estate prices will decrease eventually. This can be seen by:

$$
P=\sum_{t=0}^{T} \frac{F}{(1+i)^{t}}
$$

where $i$ is the lending rate and $F, P$ are the future and present real estate prices consecutively.

Generally the movement of the housing real estate prices is not stationary since the findings of the DF and Augmented Dickey-Fuller test (ADF 1984) formally confirm that the null hypothesis (the series has a unit root) cannot be rejected at all confidence interval levels.

So to overcome the non-stationary issue, the real estate series is transformed into a monthly logarithm house pricing series of first difference. Thus the first difference of logarithm $\Delta P_{t}$ is stationary. See Table $\mathrm{I}$.

A time series is said to be stationary if its mean, variance and its co-variances remain constant over time. From an economic point of view, shocks to a stationary time series are temporary and, over time, the effects of the shocks will be absorbed. The existence of a unit root was estimated for the original data and the absence of a unit root for the first-difference data.

So given the price level $P_{1}, P_{2}, \ldots, P_{t}$, the logarithmic first difference return at time $\mathrm{t}$ is calculated as:

$$
\ln P_{t}-\ln P_{t-1}
$$

where,

$$
\begin{aligned}
& P_{t}=\text { the real estate price at time } \mathrm{t} \\
& P_{t-1}=\text { the real estate price just preceding of the time } \mathrm{t}
\end{aligned}
$$

\section{Autoregressive Model (AR)}

According to autoregressive model, a forecast is a function of previous values of the time series (Hanke and Wichern, 2009). This model takes the following equation:

$$
P_{t}=\mu+\varphi_{1} P_{t-1}+\varphi_{2} P_{t-2}+\ldots, \varphi_{p} P_{t-p}+v_{t}
$$

where,

$$
\begin{aligned}
& P_{t}=\text { the actual rate of return at period } t \\
& P_{t-1}, P_{t-2}, \ldots, P_{t-p}=\text { the lagged dependent variables } \\
& \mu=\text { constant } \\
& \varphi=\text { co-efficient } \\
& v_{t}=\text { a white noise disturbance term }
\end{aligned}
$$

\section{Autoregressive Distributed Lag Model, $A D L(p, q)$}

$$
\begin{aligned}
& \Delta \ln Y_{t}=\mu+\varphi_{1} \Delta \ln Y_{t-1}+\varphi_{2} \Delta \ln Y_{t-2}+. .,+ \\
& \varphi_{p} \Delta \ln Y_{t-p}+\delta_{1} X_{t-1}+\delta_{2} X_{t-2}+. .,+\delta_{q} X_{t-q}+v_{t},
\end{aligned}
$$

With $p$ lags of $Y_{t}$ and $q$ lags of $X_{t}$.
$\Delta \ln Y_{t}=$ the first logarithmic difference of average house prices at period $\mathrm{t}$

$\Delta \ln Y_{t-1}=$ The lagged dependent variables

$\Delta X_{t-1}=$ The lagged predictor variable, lending rate

$\mu=\mathrm{constant}$

$\varphi=$ co-efficient

$\delta=$ co-efficient

$\mathrm{v}_{t}=\mathrm{a}$ white noise disturbance term

Lending rates returns should be statistically significantly negatively related to real estate prices returns.

So we can see the lead-lag relationship (ADL) between the lending rate and the real-estate returns, and test if the lagged coefficients of lending rate coefficients are statistically significant different from zero or not.

\section{EMPIRICAL RESULTS}

TABLE I: DF AND ADF TEST OF THE LOGARITHM OF THE FIRST ORDER DIFFERENCE OF HOUSE PRICES

\begin{tabular}{c|c|c|c}
\hline \hline Variable & & Statistic value & Prob* \\
\hline \multirow{4}{*}{ DF test } & t-Statistic & -2.772 & \\
& $1 \%$ level & -3.544 & \multirow{2}{*}{0.0624} \\
& $5 \%$ level & -2.909 & \\
& $10 \%$ level & -2.590 & \\
\hline \multirow{3}{*}{ ADF test } & z-Statistic & -3.150 & \\
& $1 \%$ level & -3.553 & \multirow{2}{*}{0.0231} \\
& $5 \%$ level & -2.915 & \\
\hline \hline
\end{tabular}

TABLE II: BEST LAG OF THE AR OF THE LOGARITHM OF THE FIRST ORDER DIFFERENCE OF HOUSE PRICES

\begin{tabular}{c|c|c|c|c}
\hline \hline & AIC & BIC & HQIC & SBIC \\
\hline L1 & -623.0659 & --618.4045 & -8.17372 & -8.136901 \\
L2 & -611.8393 & -604.8868 & -8.120843 & -8.065157 \\
L3 & -614.3557 & -605.1395 & -8.252422 & -8.177560 \\
L4 & -602.9538 & -591.5015 & -8.197122 & -8.102761 \\
L5 & -592.9868 & -579.3268 & -8.160398 & -8.046205 \\
\hline \hline
\end{tabular}

In general, the results show that $\mathrm{AR}(1)$ is the best fitting model among all alternative models since it has the minimum AIC, BIC, HQIC, SBIC (Scores of the model selection criteria ), see Table II .

TABLE III: OUTPUT OF THE AR (1) LOGARITHM FIRST DIFFERENCE HOUSE PRICING ESTIMATION

\begin{tabular}{c|c|c|c|c}
\hline \hline Variable & Coefficient & Std. Error & z-Statistic & Prob. \\
\hline $\mathrm{C}$ & 0.0009984 & 0.000530 & 1.88 & 0.060 \\
$\mathrm{AR}(1)$ & 0.8273649 & 0.061457 & 13.46 & 0.000 \\
\hline \hline
\end{tabular}

The coefficient of the estimated first lag of the logarithm of the difference in house pricing is statistically significant at the confidence interval $95 \%$, since the probability of this coefficient is less than 0.05 , see Table III.

Hence,the predicted change in future average housing prices is estimated by $\mathrm{AR}(1)$ which takes the following form :

$$
\Delta \ln P_{t}=0.0009984+0.8273649 \Delta \ln P_{t-1}
$$

The following table IV shows the output of the ADL $(1,3)$ estimation of the first difference logarithm of house prices. 
After several trials, we recognize that ADL of one lag of $\Delta \ln P_{t}$ and three lags of lending interest rate is the best fitting model (see Table IV).

TABLE IV: OUTPUT OF THE ADL $(1,3)$ ESTIMATION

\begin{tabular}{c|c|c|c|c}
\hline \hline Variable & Coefficient & Std. Error & t-Statistic & Prob. \\
\hline dlnprice & 0.717625 & 0.110333 & 6.50 & 0.000 \\
L1.rate & 0.003567 & 0.002230 & 1.60 & 0.114 \\
L2.rate & -0.008441 & 0.002434 & -3.47 & 0.001 \\
L3.rate & 0.002956 & 0.002401 & 1.23 & 0.222 \\
C & 0.124817 & 0.006017 & 2.07 & 0.042 \\
\hline \hline
\end{tabular}

The estimated model $\operatorname{ADL}(1,3)$ takes the following form:

$$
\begin{aligned}
& \Delta \ln P_{t}=0.124817+0.717625 \Delta \ln P_{t-1}+ \\
& 0.003567 R_{t-1}-0.008441 R_{t-2}+0.002956 R_{t-3}
\end{aligned}
$$

The coefficient of the second lag of the lending interest rate is Statistically significant at the $95 \%$ confidence interval (the probability of this coefficient is also less than 0.05)and it is negatively related to the housing price. (Table IV).

Then raising the lending interest rate by one unit is an effective negative tool to decrease the change in real estate house pricing by $0.8 \%$ after two months (Table IV).

This autoregressive distributed lag analysis confirms that the lending interest rates lead the real estate house pricing changes. Thus, raising the present interest lending rate will lead to a negative decrease in the real estate prices in the future by minimum two period-lags. (Table IV).

\section{CONCLUSION}

China should cool off the housing market increase and the high-inflation by raising interest rates and taking proactive quick actions in the monetary policy or else there will be another Japan 1980 asset bubble burst.

Hence, in this paper we mainly have studied the lead-lag relationship between the lending rates and the real estate housing prices. And results have shown that housing prices respond negatively to increase in lending rates after two months (the second lag of the lending rate is statistically significant at all confidence levels). The Chinese Central bank should raise the lending interest rate and the decrease effect of real estate house prices will emerge easily after two months.

If the real estate burst, then investors will sell more stocks to cover the huge losses in the real estate market. It will take China decades to recover back and boost again its growth in all financial sectors. China should learn from the Japanese bubble burst (1980) experience since if the bubble burst, China might face severe and devastating economic and social consequences. For example, harsh losses in the stock market and small investors will be in a miserable case. Homeowners should pay their mortgage when the real value of their property continued to decline more. Non-performing loans will increase roughly too and banking sector will face a serious crisis. Inflation then deflation will have serious effects on China's economy where it will affect other commodities like copper and steel.

China's government must be extremely cautious and should immediately adopt the correct monetary policy to deal with the real estate bubble and avoid its economy burst. As we said, interest rates, deposit reserve ratios and exchange rates should be all increased carefully and if China didn't implement these proactive measures then it will take the economy long time to recover from the deflation and even late correct interest rate policy couldn't bail-out the whole crisis.

\section{REFERENCES}

[1] Asset-based economy. [Online] Available: http://en.wikipedia.org/wiki/Asset-based_economy

[2] N. G. Mankiw and N. D. Weil, "The baby boom, the baby bust, and the housing market," Regional Science and Urban Economics, vol. 19, no. 2, pp. 235-258, May 1989.

[3] H. P. Hendershott, "Are real house prices likely to decline by 47 percent," Regional Science and Urban Economics, vol. 21, no. 4, pp. 553-563, December 1991.

[4] D. D. Pasquale and W. C. Wheaton, "Housing market dynamics and the future of housing prices," Journal of urban economics, vol. 35, no. 1, pp. 1-27, Jan 1994.

[5] K. E. Case and R. A. Shiller, "Decade of boom and bust in the prices of single family homes: Boston and Los Angeles," New England Economic Review, pp. 40-51, 1994.

[6] J. M. Clapp and C. Giaccotto, "The influence of economic variables on local house price dynamics," Journal of Urban Economics, vol. 36, no. 2, pp. 161-183, September 1994.

[7] J. A. Kahn, "Productivity swings and housing prices on the use of economics and finance," Swiss Finance Institute, July 2009.

[8] J. Baffoe-Bonnie, "The dynamic impact of macroeconomic aggregates on housing prices and stock of houses: a national and regional analysis," The Journal of Real Estate Finance and Economics, vol. 17, no. 2, pp. 179-197, Sep 1998.

[9] J. Clapp, and G. Carmelo, "Evaluating house price forecasts," Journal of Real Estate Research, vol. 24, no. 1, pp. 1-26, January 2002.

[10] G. W. Crawford and M. C. Fratantoni, "Assessing the forecasting performance of regime-switching, ARIMA and GARCH models of house prices," Real Estate Economics, vol. 31, no. 2, pp. 223-243, July 2003.

[11] M. Iacoviello, "House prices, borrowing constraints, and monetary policy in the business cycle," The American Economic Review, vol. 95, no. 3, pp. 739-764, June 2005.

[12] M. Iacoviello, and R. Minetti, "The credit channel of monetary policy: Evidence from the housing market," Journal of Macroeconomics, vol. 30, no. 1, pp. 69-96, Mar 2008.

[13] C. Vargas-Silva, "Monetary policy and the US housing market: A VAR analysis imposing sign restrictions," Journal of Macroeconomics, vol. 30, no. 3, pp. 977-990, September 2008.

[14] R. Gupta, M. Jurgilas, and A. Kabundi. "The effect of monetary policy on real house price growth in South Africa: A factor-augmented vector autoregression (FAVAR) approach," Economic Modeling, vol. 27, no 1 , pp. 315-323, January 2010.

[15] R. Gupta and S. Das, "Predicting downturns in the US housing market: A Bayesian approach," The Journal of Real Estate Finance and Economics, vol. 41, no. 3, pp. 294-319, October 2010.

[16] I. A. Boitan, and I. A. Boitan, "Residential property prices' modeling: evidence from selected European countries," Journal of European Real Estate Research, vol. 9, no. 3, pp. 273-285, November 2016.

[17] L. F. Skarbøvik, "Forecasting House Prices in Norway: A Univariate Time Series Approach," M.S. thesis, Dept. Business Administration, Universiteteti Troms $\emptyset$, Troms $\emptyset$, Norway, 2013.

[18] D. Q. Do and K. G. M. Holten, "House prices in Denmark," An in-depth Analysis of the Price, Dept. Business Administration, Aarhus University, Aarhus, Denmark, 2013.

[19] K. C. Chan and C. H. Chang, "Analysis of bond, real estate, and stock market returns in China," Chinese Economy, vol. 47, no. 2, pp. 27-40, March 2014

[20] J. C. Harris, "The effect of real rates of interest on housing prices," The Journal of Real Estate Finance and Economics, vol. 2, no. 1, pp. 47-60, February 1989.

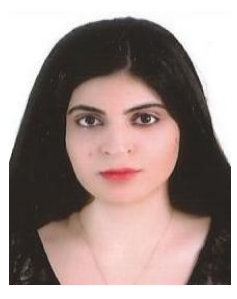

J. Salim was born in Lebanon on January 11, 1991 She is currently a finance $\mathrm{PhD}$ scholar at the School of Economics, Shandong University, Jinan City, China from 2015 to 2018.

She obtained the master degree of actuarial sciences in 2014 and the bachelor degree of mathematics in 2011 from the Lebanese University.

Her major research interests are in the fields of Financial Econometrics, Risk Management Modeling, 
Data Mining and Classification.

She did an internship at Finance-In-Motion, and participated in conducting the Due Diligence (DD) and reporting the balance sheet of the potential investees for ensuring their minimum standards of eligibility for the purpose of on lending to MSMEs.

She also did an internship for three months in 2013 at the Risk Management Department, Blom Bank s.a.l-Lebanon in the partial fulfillments of her master's degree.

Miss Salim earned her PhD scholarship from the Lebanese Ministry of Education and Chinese Government Scholarship (CSC).

She also earned the second place for the best presentation award at the IC-SMHD-May 2016 (International Conference on Information Complexity and Statistical Modeling in High Dimensions with Applications) in Turkey.

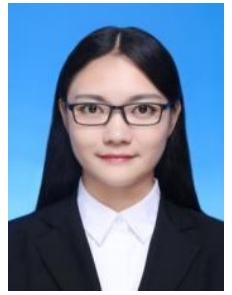

X. Fang was born in Anqing city, Anhui Province, P.R. China in October 1990. She is currently a PhD student of Shandong University, in Jinan, Shandong Province. Her major research interests are in corporate finance.

She took part in many academic researches, including "Research of Systemic Financial Risk Precaution and Regulatory Mechanisms to Coordinate", the national social science fund project subject to tender, and participating in applying for the project as a core member of "Bank Governance Capital Management and Governance Risk", major projects of Humanities and Social Science, Ministry of Education, participating in applying for the project as a core member.

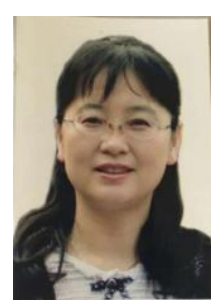

Y. Ren was born in China on October 4, 1967. She is currently a professor at the school of economics, Shandong University, Jinan city, China from 2006. Her major research interests are in the fields of financial econometrics and financial engineering. 